\title{
INADEQUATE ACCESSION DATA COMPROMISES THE CONSERVATION VALUE OF PLANT COLLECTIONS
}

\author{
Cathy Badley, David Hill \& Nicholas WraY*
}

The accession data quality and record keeping at 21 botanic gardens, 35 gardens with National Council for the Conservation of Plants and Gardens (NCCPG) collections, and eight other significant gardens in the UK was surveyed in January 2001, with special reference to Hebe.

Nearly half of all the gardens in the survey had no written policies or procedures on accessions. This correlated significantly $(\mathrm{p}<0.05)$ with poorer quality accession data. Only $14 \%$ of botanic gardens and $17 \%$ of NCCPG gardens recorded all the minimum accession data fields recommended by the Botanic Gardens Conservation International (BGCI). Only a third of all types of garden stored all their data on computer; a third of the botanic gardens updated their data less frequently than every two years, and the information transferred from the accession records to labels was sometimes scant. There was a significant negative correlation between the average number of accessions per member of staff, and accession data quality - more than 250 accessions per member of staff often corresponding to poor data quality.

We challenge the view that botanic gardens should only concentrate on plants from the local indigenous flora (Action Plan for Botanic Gardens in the European Union, BGCI 2000) because it restricts the educational role and research potential of the garden and limits the world-wide collections of endangered species being kept safe from indigenous hazards. However, with a need to limit the plants in gardens to a manageable number with good records, criteria will be needed to select which species to represent in collections. A list of criteria, developed from a review of the Hebe collection in the University of Bristol Botanic Garden, is suggested for all plants in botanic and similar gardens.

\section{INTRODUCTION}

Animal and plant collections in zoological and botanic gardens have many common aims, the most important being display for educational purposes, conservation of the species in their charge and the maintenance of reference collections for research. However, a survey of 119 European botanic gardens in 29 countries in 1999 found that the majority of the plant collections were small; they contained a large proportion of non-wild origin accessions and many of the collections had poor accession data (Maunder et al, 2001). A review of ex situ collections in botanic gardens world-wide, reported in 2001 by The World Conservation Union (IUCN) (BGCI, 2001), estimated that in the UK $70-80 \%$ of these collections were set up before the Convention on

\footnotetext{
* Cathy Badley is a Friend of the University of Bristol Botanic Garden and recently completed an MSc at the University of Bristol. Address: University of Bristol Graduate School of Education, 35 Berkeley Square, Clifton, Bristol, BS8 1JA. E-mail: cathy.badley@bris.ac.uk

David J Hill is Senior Lecturer in the School of Biological Sciences at the University of Bristol. Address as above.

Nicholas Wray is the Curator of the University of Bristol Botanic Garden. Address: University of Bristol Botanic Garden, Bracken Hill, North Road, Leigh Woods, Bristol BS8 3PF.
} 
Biological Diversity (CBD) was established in 1993 and many had subsequently never conformed to the standards of recording data recommended by the Convention.

Resources spent in botanic gardens on the conservation of collections are largely wasted if the identities of the plants have not been verified, the provenance is unknown, the position of the plants in the garden and the dates they were acquired are not recorded. Similarly, when plants die or are removed from the garden, confusion can occur if the records are not amended. The Darwin Technical Manual for Botanic Gardens, produced by the BGCI in 1998, gives comprehensive guidance on botanic garden data maintenance - but it is not known how closely this advice is being followed. The Manual states that the key components of good accession data management are that:

a. the institute has written policies concerning the accession of plants and collection management;

b. the data is stored on computer with a secure back-up system in place;

c. the records always include the definitive data about each accession (accession number, name, date obtained, propagule type, source, and location of the plant in the garden);

d. the accession data are routinely transferred to the labeling system throughout the life of the plant; and

e. the database is continuously updated.

The aim of this research is to compare the accession data quality with the recommendations listed above, with reference to a well-known genus of plants, in collections held in the UK by botanic gardens, other significant gardens, and gardens with National Council for the Conservation of Plants and Gardens (NCCPG) collections. NCCPG Gardens were included as the stated aim of the NCCPG is to conserve garden plants. The genus Hebe was chosen because it is commonly grown in the UK and many species come from remote and threatened habitats in New Zealand.

The recommendation of the Action Plan for Botanic Gardens in the EU (BGCI, 2000 ) is for EU gardens to conserve EU plants as a priority. However, non-indigenous collections are often kept for educational purposes, as a resource for research and for year-round interest. Traditionally, botanic gardens grow plants from other parts of the world, especially from the areas where the habitat is threatened, to encourage a worldwide view of plant conservation. If a garden is to include such plants in their collections, good records need to be kept and resources allocated to them. Since resources are limited, appropriate criteria are needed to select suitable indigenous and exotic genera and species and our second aim is to propose a number of such criteria as a working checklist for further consideration by botanic gardens.

\section{SURVEY METHOD}

\section{Selection of Gardens}

Gardens in the UK with significant exotic Southern Hemisphere collections including those of Hebe species were selected using the PlantNet Directory (PlantNet, 1999), the NCCPG Handbook (NCCPG, 2001) and advice from the NCCPG Head Office (Johnson, 2002). In this report gardens are classified as: Botanic (a garden which describes itself as such); NCCPG (any non-botanic garden which has an NCCPG National Collection) and Other (any significant gardens which did not fit into the 
above categories e.g. National Trust, local authorities, the Crown, private owners, nursery owners etc which had an interest in conservation or collected plants from the wild).

The aim was to collect data on the quantity, standard and storage methods of accession records at all types of gardens and to compare those of botanic gardens with those of NCCPG collection holders and other types of gardens. Information from the questionnaires relating to the genus Hebe was used to assess the quality of the accession data of Hebe taxa collections in the UK.

Questionnaires were sent to the selected gardens. There were three types of questionnaire, designed for:

a. Gardens with Hebe collections;

b. Gardens which sent out expeditions (to investigate methods of verification and recording the location of collected plants); and

c. NCCPG gardens with exotic collections, some of which were of Hebe species.

Each type of questionnaire was divided into two sections, the first part common to all three types of questionnaires, the second part specific to the group concerned (see Table 1). The draft questionnaires were piloted by two botanic gardens and one garden with NCCPG collections and revised before being sent out to the target gardens in January 2001.

TABLE 1. Content and distribution of questionnaires

\begin{tabular}{|c|c|c|c|}
\hline $\begin{array}{l}\text { Section } 1 \\
\text { - } \quad \text { written policy and } \\
\text { procedure } \\
\text { concerning } \\
\text { accessions; } \\
\text { - } \quad \text { year records started; } \\
\text { - } \quad \text { BGotographic } \\
\text { records; } \\
\text { - } \quad \text { how the data are } \\
\text { kept; } \\
\text { - } \quad \text { software used; } \\
\text { use of ITF } \\
\text { (International } \\
\text { Transfer } \\
\text { Format for } \\
\text { Botanic Garden } \\
\text { Records, 2002); } \\
\text { data recorded for } \\
\text { each accession } \\
\text { now and ten } \\
\text { - } \text { years ago; } \\
\text { data transferred to } \\
\text { plant labels; } \\
\text { how plant locations } \\
\text { arre recorded; } \\
\text { collections; }\end{array}$ & $\begin{array}{l}\text { Questionnaire 2-Gardens } \\
\text { with Expeditions } \\
\text { - } \quad \text { frequency and } \\
\text { destination of } \\
\text { expeditions; } \\
\text { how location of } \\
\text { collection sites are } \\
\text { determined; } \\
\text { how plant identity is } \\
\text { verified; } \\
\text { how collected samples } \\
\text { are used in the garden. }\end{array}$ & $\begin{array}{l}\text { Sent to } \\
\text { Questionnaire } 1 \text { Sent to } 20 \\
\text { botanic gardens, } 17 \text { NCCPG } \\
\text { gardens, and } 9 \text { other significant } \\
\text { gardens which were: } \\
\text { - All the gardens in the } \\
\text { PlantNet Directory } \\
\text { (PlantNet, 1999) with New } \\
\text { Zealand plant or genus } \\
\text { Hebe collections; } \\
\text { National Collection Holders } \\
\text { of Hebe taxa; } \\
\text { Large nurseries which } \\
\text { specialised in Hebe taxa. }\end{array}$ & $\begin{array}{l}\text { No of Replies } \\
35(76 \%) \\
\text { (19 botanic } \\
\text { gardens, } 10 \\
\text { NCCPG } \\
\text { gardens, } 6 \\
\text { 'Other' } \\
\text { gardens) }\end{array}$ \\
\hline - accession & Questionnaire 3-NCCPG & Questionnaire 3: Sent to 1 & $22(69 \%)$ \\
\hline
\end{tabular}




\begin{tabular}{|c|c|c|c|}
\hline $\begin{array}{l}\text { numbering } \\
\text { system; } \\
\text { - } \quad \text { frequency of } \\
\text { updating of } \\
\text { records; } \\
\text { - use of bar code } \\
\text { system. } \\
\text { (Responses from } 21 \\
\text { botanic gardens, } 35 \\
\text { NCCPG gardens, } 8 \text { 'Other' } \\
\text { gardens) }\end{array}$ & $\begin{array}{l}\text { Collection Holders } \\
\text { - } \quad \text { the size and contents of } \\
\text { collections; } \\
\text { date started and } \\
\text { registered with the } \\
\text { NCCPG; } \\
\text { how many live } \\
\text { specimens are } \\
\text { collected from wild; } \\
\text { arrangement of } \\
\text { collections; } \\
\text { how self-sown hybrids } \\
\text { are eliminated. }\end{array}$ & $\begin{array}{l}\text { botanic garden and } 31 \text { NCCPG } \\
\text { gardens selected on advice from } \\
\text { the NCCPG Head Office } \\
\text { (Johnson, 2002), and the NCCPG } \\
\text { Directory (NCCPG, 2001). }\end{array}$ & $\begin{array}{l}\text { (1 botanic } \\
\text { garden and } \\
21 \text { NCCPG } \\
\text { gardens, with } \\
49 \text { NCCPG } \\
\text { collections) }\end{array}$ \\
\hline
\end{tabular}

\section{METHODS OF ANALYSIS OF RESULTS}

Data were taken from the written questionnaires and collated in two separate procedures. First, the responses to each question were scored and the median found for each type of garden (Botanic, NCCPG and 'Other') and then these medians were compared (Appendix 1). Second, each individual garden's responses were scored and summed to give a total score for each garden which gave an indication of the quality of the accession data for each individual garden (Table 2). This total score was then compared with those of other gardens and tested against the theoretical maximum score.

Where the questions were common to all questionnaires, the results of all 64 respondents were used. To investigate the significance of the non-parametric data obtained from the questionnaires, the statistical tests used were the Chi-squared Test, the Mann-Whitney Test and the Spearman Correlation (Siegal \& Castellan, 1998).

TABLE 2. Scoring of the questions to assess the accession data quality of individual gardens

\section{Question}

Does the garden have a written accession policy?

Does the garden have a written accession procedure for new accessions?

Are the accession data partly or wholly stored on computer?

What accession data are recorded?

(The six basic fields listed in the Introduction)

What accession data are transferred to the plant label?

- Accession Number

- Latin Name

- Date Obtained

- Source

How frequently are the data updated?

\section{Score}

$Y e s=1$ point, $\mathrm{No}=0$

$Y e s=1$ point, $\mathrm{No}=0$

$Y e s=1$ point, $\mathrm{No}_{\mathrm{O}} \mathrm{0}$

Yes $=1$ point, No $=0$ for each type of data recorded (maximum 6 points)

1 point for always including data, half a point if only sometimes put on label (maximum 4 points)

At least every two years or more frequently scores 1 point

14 POINTS 


\section{RESULTS}

\section{Quality of Accession Data}

Over two thirds of gardens asked responded to the questionnaires: 21 botanic gardens, 35 gardens with NCCPG collections and 8 other gardens. Of these, 24 had collections of Hebe species (Table 1). The results are summarised in Appendix 1. Nearly half the botanic gardens and two-thirds of NCCPG gardens in the survey had no written accession policies and procedures. Three quarters of 'Other' gardens had no written policies and none had written procedures. Fewer gardens of all types had written procedures than written policies. The recording of the six recommended basic accession data fields (accession number, name, date acquired, propagule type, location, and provenance) was very variable. Only $14 \%$ of botanic gardens and $17 \%$ of NCCPG gardens recorded data in all fields (none of the 'Other' gardens). Accession location in the garden was not recorded by 14\% botanic, 29\% NCCPG and 13\% 'Other' gardens. Only two gardens used a Global Positioning System (GPS) in the garden and yet half the gardens that sent expeditions used a GPS device to identify the location of the habitat, in conjunction with a description or map grid reference.

Just over a third of all types of gardens stored all their accession data on computer. However, $10 \%$ of botanic, $23 \%$ of NCCPG and $40 \%$ of 'Other' gardens did not use a computer at all. Several software systems have been produced specifically for botanic and other gardens for the recording of plant data. The most popular are BG-Recorder2 produced by the $\mathrm{BGCI}$, and $B G-B A S E$ which is similar (BGCI, 1998). In this survey $40 \%$ of botanic gardens and $9 \%$ of NCCPG and 'Other' gardens used $B G-B A S E$ or BG-Recorder. Microsoft spreadsheet/database software was used more by NCCPG gardens (over half) than botanic or 'Other' gardens (less than a quarter). At present only $45 \%$ of botanic, $23 \%$ of NCCPG and none of the 'Other' gardens use the International Transfer Format for Botanic Gardens (ITF) which was designed to allow botanic gardens to share data on line (International Transfer Format, 2002). A further third of all gardens reported that they intended to use ITF in the future, which would increase the proportion of gardens to $75 \%$ of those surveyed.

The amount of accession data transferred to the plant labels varied between all the gardens in the survey. A number of other fields were often added to labels. Nearly a quarter of all gardens did not put the accession number on the label, and $14 \%$ did not always include the Latin name on the label. Details about the indigenous area of the species were added by about half the gardens. Only one garden used a barcode system for labels: many had considered it but found it too expensive to install.

A statistical analysis of the individual garden scores showed that there was a significant association between the existence of both a written policy and written procedure in a garden (all types), and the quality of its accession data (Chi-squared Test, $\mathrm{p}<0.001$ ). There was also a significant negative correlation between the quality of accession data and the number of accessions per member of staff in all types of garden (Spearman Rank Correlation test $\mathrm{p}<0.05$ ). More than 250 accessions per member of staff correlated with poorer accession data quality scores. However, there was not a significant correlation between the size of the garden and accession data quality (Spearman Rank Correlation test, $\mathrm{p}>0.05$ ). 
The survey indicated that botanic gardens owned by trusts had significantly better quality accession data than botanic gardens owned by other organisations, e.g. universities, local authorities (Chi-squared test $\mathrm{p}<0.01$ ). All the gardens which sent expeditions used several methods to ensure that the plants found were correctly identified. These included reference to the Royal Botanic Gardens Kew or a local expert, reference books, herbarium samples or a National Reference Collection.

The questionnaires asked respondents which data were collected routinely ten years ago. The results showed that, although the quantity of data now recorded is generally more comprehensive in all types of gardens, it still often does not meet the minimum recommendations of the BGCI.

\section{Comparison between accession data quality in Botanic and NCCPG gardens}

There was no significant difference in the level of accession data recording between the two types of garden (Mann-Whitney test $\mathrm{p}>0.05$ ). However, all the NCCPG respondents updated their data either on a continuous basis or more than every two years, compared with two-thirds of botanic gardens.

\section{Genus Hebe collections in the UK}

Although many gardens surveyed included Hebe species in their collections, only 16 gardens in this survey in the UK had Hebe taxa collections which contained more than 11 species. Of these, 13 gardens had good accession data and could form the nucleus of a multi-locational collection. Nine of these were botanic gardens. The four largest and best-documented collections together contained almost half of all known Hebe species including four which are on the IUCN Red List (IUCN, 1997). Few species were duplicated between these gardens and often only one individual clone of a species was held in a garden.

The owners of the NCCPG National Collections of genus Hebe and the National Reference Collection only produced a list of names of plants in their collections with no further information. Two collections of these were in the process of being moved. Over half the gardens in the survey had working relationships with New Zealand horticulturists and two thirds had more than six Hebe taxa specimens directly derived from material from New Zealand.

\section{DISCUSSION}

\section{Accession data}

This study revealed that plant record keeping at many gardens has not improved dramatically since concern was originally expressed by the IUCN in 1984 (IUCN 1989) and by Maunder et al in their survey of European botanic gardens in 1999 (Maunder et al 2001).

The educational, conservation and research value of a collection is largely dependent on the quality of its accession data. But the resource costs of maintaining a collection are being wasted because accession data is not easily available to researchers and conservationists, and the data are not being kept up to date. The new Convention on International Trade in Endangered Species of Wild Fauna and Flora (CITES) as 
well as the $\mathrm{CBD}$ require that certain data is recorded. As botanic gardens work together more closely under the auspices of the BGCI and the World Conservation Monitoring Centre, gardens which do not record and update the required data will not be able to contribute to conservation work and may become discredited and their collections redundant.

Botanic gardens could use accession data quality as criteria when prioritising resources available for the maintenance of plants: well disciplined collections of merit with good records being given resources over those which do not. Individual plants which have neither special reasons for being kept nor good documentation should be replaced in time with those which have good records.

The botanic gardens which took part in this survey ranged from very small to three of the largest botanic gardens in the UK. Amongst the NCCPG collection holders there were small private owners and large local authority parks departments, as well as gardens belonging to charities such as the National Trust. There could be a number of reasons why accession data is poor in both botanic and other types of gardens. However, this situation may have arisen because, until recently, the significance of accession data was not recognised by many gardens.

The problem of inadequate plant records at some gardens is exacerbated by the lack of use of computers. These gardens are unable to liaise with other collection holders, keep good stock control records and produce plant labels, publicity and educational material quickly and cheaply. More resources in botanic gardens should be allocated to computing.

The NCCPG collections are an important reservoir of genetic stock and therefore have a potentially valuable conservation role. Many of the administrative problems of these collections are similar to those in botanic gardens. The stated aim of the NCCPG is to preserve garden plants, which are often unusual sports or cultivars. However, it was found in this survey that the NCCPG collections also contained substantial numbers of species, many originating directly from their natural habitat. The monitoring and maintenance of these collections is run on a voluntary basis by both amateurs and professional horticulturists, and the quality of the data relies on the collection owners' enthusiasm and commitment. Despite these varying levels of curatorial skills, the quality of the accession data for these gardens was not found to be significantly different from those of botanic gardens (Mann-Whitney test $\mathrm{p}>0.05$ ). However, it was observed that, in all nine of the NCCPG gardens visited in the course of this survey, the educational potential of these collections was not fully exploited.

\section{Plant labelling}

It is a frequent experience amongst regular visitors to botanic and other significant gardens that plants are either unlabelled, have the wrong label or an inadequate display of information. Possibly some gardens are over-ambitious with the numbers of plants in their care and should aim to have smaller collections kept to a higher standard. Future research is needed to overcome the many practical problems with labelling plants in gardens. This study showed that where plants are labelled, most gardens transfer the Latin name and accession number to the permanent labels, but only a half add information about the geographical area and a only quarter add the source, date or common name, or other information (Appendix 1). Thus the educational value of these plants is often lost. The use of bar codes on labels or on microchips inserted in the 
plant or root mass may be a possible solution for some types of plant. However, the gardens in this survey were reluctant to invest in labels using this system owing to the cost of the equipment.

\section{GRADING EX SITU CONSERVATION COLLECTIONS}

The IUCN, BGCI and, in the UK, PlantNet, produce a considerable amount of information with recommendations about plant collection maintenance and documentation, but this study has shown that in many gardens these are not used. In many cases this may be due to the lack of available resources. The European Community has already recognised the need and importance of data collection of many types and has set up a funding system for some data collection schemes, though not, so far, in horticulture (Eurostat Project, 2002).

An international system of grading and auditing of plant collections would ensure that gardens maintained their collections to a specified minimum standard relating to the purpose of their collections. This could also relate to recognised standards for research, education and communal use. Collections could be graded from 1 to 5 based on: number of species/genotypes and provenance, verification level, existence of field gene banks, quality of accession data, educational value and display, and relevance to active research programmes. These criteria would need to be established by the IUCN and the collections audited regularly either by the IUCN or other botanic gardens. Given the funding and staffing restraints in many gardens, it may be more practical for gardens to concentrate on building the quality of a few significant collections rather than trying to monitor all the plants in the garden. This could have more benefit to conservation world-wide.

\section{CHOOSING SPECIES/GENERA FOR AN EX SITU COLLECTION}

As the results of this survey focus attention on the careful selection of which plants to retain or acquire, a check list (Appendix 2) for the choice of genus/species to be included in a conservation collection at a botanic garden was drawn up, using the literature and experience of renovating the Hebe collection at the University of Bristol Botanic Garden.

The University of Bristol Botanic Garden accession data books started in 1973 and are probably typical of pre-CBD accession data. The early manual entries consisted of the name of the plant, a brief description of a mature specimen and a note of its provenance (often just initials or a name). The date of accession and the location of the plant in the Garden had not been recorded. The data had not been routinely updated in the past and very few entries had been deleted. (Entries are now routinely updated.) When this survey was carried out the Hebe taxa accession entries numbered 200 but only 73 recognisable accessions were still growing in the garden.

At the start of the project this collection was in a mature state with many of the faster growing species and hybrids having filled the space allocated to them. A major reorganisation and replanting of the collection had been undertaken nine years earlier as part of the ongoing maintenance of the collections. A repeat of this work took place in parallel with this research project, which resulted in many of the larger specimens being replaced with new plants propagated on site. Many of the slower growing species, some of which were over 20 years old, were in need of only light formative 
pruning. The majority of the collection had been gathered together some 25 years previously and had been laid out to illustrate the diversity within the genus and to show the relationship between the principal parents, hybrids and cultivars.

This study has shown that gardens which have written accession policies tend to have more comprehensive accession records. This may often be due to more available resources, but where funding is restricted it is even more important that the collections are chosen carefully to gain maximum educational and conservation benefit from minimum expenditure and maintenance costs. The criteria list proposed here is designed for choosing plants for an ex situ collection, which could be used to demonstrate principles of ecology, conservation, and botany. It covers three aspects of selection:

a. resources and suitability of the growing site, for example, staffing and maintenance costs;

b. the properties of the species, for example, the Red Book status, whether it has ecological significance or ethnobotanic uses; and

c. whether the collection can be used for research and educational purposes and how this can be displayed to best advantage, e.g. a local research programme already in progress; a clear educational theme to the collection.

As far as concentrating on indigenous species is concerned, as recommended by the Action Plan for Botanic Gardens in the EU, it may be that a more realistic role for botanic gardens is to represent the intellectual voice in the management of local nature reserves and natural habitats as well as keeping collections of exotic plants for educational purposes.

\section{REVIEW OF THE GENUS HEBE IN COLLECTIONS IN THE UK}

The survey showed that although many gardens included Hebe species in their collections, these were sometimes poorly documented and many only included a few samples. However, the better documented collections, taken together, had examples of over half the existing known Hebe species. Despite this, it would be difficult to use the existing collections as part of a multi-locational Hebe taxa conservation collection at present because the quality of the accession data in the gardens with Hebe taxa collections is sometimes poor. This would hamper the sharing of data and throw doubt on the identity and provenance of existing collections. Currently the degree of liaison between gardens is variable, although 30 of the 34 gardens with Hebe taxa collections in this survey belong to either PlantNet or NCCPG (many belong to both). However, not all the gardens involved have the equipment or resources to operate a computerised database. Few gardens currently publish their accession data on websites although many garden websites mention special collections held in gardens and their purpose.

No garden in the UK at present propagates Hebe species in large numbers as breeding populations. Space is limited in many gardens and large field gene collections would be extremely difficult to accommodate. However, Hebe taxa are already used widely for amenity planting in the UK and it would be relatively simple to use endangered species for this purpose, instead of the more common hybrids and cultivars, to horticultural and conservation advantage. 


\section{REFERENCES}

BGCI (1998). Leadlay, E. \& Greene, J. (Eds). The Darwin Technical Manual for Botanic Gardens. Richmond, Surrey: BGCI.

BGCI (2000). Action Plan for Botanic Gardens in the European Union. Objective C2. p. 35. National Botanic Garden of Belgium: BGCI.

BGCI (2001). Review of ex situ collections in botanic gardens of the world. [On line] Available at: http://biodiv.org/programmes/socio-eco/benefit/botgards.asp (Accessed August 2002).

Eurostat Project (2002). [On line] Available at: <http://europa.eu.int/comm/eurostat/> (Accessed March 2002).

International Transfer Format (2002). [On line] Available at: <http://www.bgbm.fuberlin.de/TDWG/acc/itf2tdwg.htm> (Accessed July 2002).

IUCN (1989). Botanic Gardens Conservation Strategy. Kew, UK: IUCN Botanic Gardens Conservation Secretariat.

IUCN (1997). IUCN Red List of Threatened Plants. [On line] Gland Switzerland 1997. Available at: <URL:www.wcmc.org.uk/species/plants/red_list.htm $>$ (Accessed 7 January 2002).

JoHNSON, R. (2002). Personal communication by e-mail June 2002. Ms R Johnson is the NCCPG Plant Conservation Officer.

Maunder, M., Higgens, S. \& CulHam, A. (2001). The effectiveness of botanic garden collections in supporting plant conservation: a European case study. Biodiversity and Conservation 10: pp. 383-401.

NCCPG (2001). The National Plant Collections Directory 2001. Wisley, Surrey: National Council for the Conservation of Plants and Gardens.

PlantNet (1999). PlantNet directory of botanical collections in Britain and Ireland. Comp. Cubey, R. \& Rae, D. Cambridge: PlantNet.

Siegal, S. CASTELlan, N.J. (1988) Nonparametric Statistics for the Behavioural Sciences. $\left(2^{\text {nd }}\right.$ Ed.) pp. 191-200, 128-137, 235-245. Singapore: McGraw-Hill Book Co. 
APPENDIX 1

\section{Results of Questionnaires}

\begin{tabular}{|c|c|c|c|c|c|c|c|c|c|c|c|c|c|}
\hline \multirow[b]{2}{*}{ QUESTION } & \multirow[b]{2}{*}{ DETAILS } & \multicolumn{3}{|c|}{ Botanic Gardens (21) } & \multicolumn{3}{|c|}{ NCCPG Gardens (35) } & \multicolumn{3}{|c|}{ Other Gardens (8) } & \multicolumn{3}{|l|}{ TOTALS } \\
\hline & & Yes & No & N/A & Yes & No & N/A & Yes & No & N/A & Yes & No & N/A \\
\hline $\begin{array}{l}\text { Garden has } \\
\text { written } \\
\text { accession } \\
\text { policy }\end{array}$ & & $\begin{array}{l}12 \\
(57.1 \%)\end{array}$ & $\begin{array}{l}8 \\
(38.1 \%)\end{array}$ & $\begin{array}{l}1 \\
(4.8 \%)\end{array}$ & $\begin{array}{l}13 \\
(37.1 \%)\end{array}$ & $\begin{array}{l}21 \\
(60.0 \%)\end{array}$ & $1(2.9 \%)$ & $\begin{array}{l}2 \\
(25.0 \%)\end{array}$ & $\begin{array}{l}5 \\
(62.5 \%)\end{array}$ & $\begin{array}{l}1 \\
(12.5 \%)\end{array}$ & $\begin{array}{l}27 \\
(42.3 \%)\end{array}$ & $\begin{array}{l}34 \\
(53.1 \%)\end{array}$ & $3(4.7 \%)$ \\
\hline $\begin{array}{l}\text { Garden has } \\
\text { written } \\
\text { accession } \\
\text { processing } \\
\text { procedure }\end{array}$ & & $\begin{array}{l}10 \\
(47.6 \%)\end{array}$ & $\begin{array}{l}9 \\
(42.9 \%)\end{array}$ & $\begin{array}{l}2 \\
(9.5 \%)\end{array}$ & $\begin{array}{l}10 \\
(28.6 \%)\end{array}$ & $\begin{array}{l}24 \\
(68.6 \%)\end{array}$ & $1(2.9 \%)$ & 0 & $\begin{array}{l}7 \\
(87.5 \%)\end{array}$ & $\begin{array}{l}1 \\
(12.5 \%)\end{array}$ & $\begin{array}{l}20 \\
(31.3 \%)\end{array}$ & $\begin{array}{l}40 \\
(62.5 \%)\end{array}$ & $4(6.3 \%)$ \\
\hline $\begin{array}{l}\text { Accession } \\
\text { location in } \\
\text { garden is } \\
\text { recorded }\end{array}$ & & $\begin{array}{l}16 \\
(76.2 \%)\end{array}$ & $\begin{array}{l}4 \\
(19.1 \%)\end{array}$ & $\begin{array}{l}1 \\
(4.8 \%)\end{array}$ & $\begin{array}{l}25 \\
(71.4 \%)\end{array}$ & $\begin{array}{l}6 \\
(17.1 \%)\end{array}$ & $\begin{array}{l}4 \\
(11.4 \%)\end{array}$ & $\begin{array}{l}6 \\
(75.0 \%)\end{array}$ & $\begin{array}{l}1 \\
(12.5 \%)\end{array}$ & $\begin{array}{l}1 \\
(12.5 \%)\end{array}$ & $\begin{array}{l}47 \\
(73.4 \%)\end{array}$ & $\begin{array}{l}11 \\
(17.2 \%)\end{array}$ & $6(9.4 \%)$ \\
\hline $\begin{array}{l}\text { Garden uses } \\
\text { ITF } \\
\text { ( } 20 \text { botanic, } \\
13 \text { NCCPG } \\
\text { and } 8 \\
\text { 'Other' } \\
\text { gardens) }\end{array}$ & & $\begin{array}{l}9 \\
(45.0 \%)\end{array}$ & $\begin{array}{l}9 \\
(45.0 \%)\end{array}$ & $\begin{array}{l}2 \\
(10 \%)\end{array}$ & $\begin{array}{l}3 \\
(23.1 \%)\end{array}$ & $\begin{array}{l}7 \\
(53.8 \%)\end{array}$ & $\begin{array}{l}3 \\
(23.1 \%)\end{array}$ & 0 & $\begin{array}{l}3 \\
(37.5 \%)\end{array}$ & $\begin{array}{l}5 \\
(62.5 \%)\end{array}$ & $\begin{array}{l}12 \\
(29.3 \%)\end{array}$ & $\begin{array}{l}19 \\
(46.3 \%)\end{array}$ & $\begin{array}{l}10 \\
(24.4 \%)\end{array}$ \\
\hline \multirow[t]{2}{*}{$\begin{array}{l}\text { Method of } \\
\text { keeping data }\end{array}$} & $\begin{array}{l}\text { All data } \\
\text { on } \\
\text { computer }\end{array}$ & $\begin{array}{l}8 \\
(38.2 \%)\end{array}$ & $2(9.5 \%)$ & - & $14(40 \%)$ & $\begin{array}{l}8 \\
(22.9 \%)\end{array}$ & - & $\begin{array}{l}3 \\
(37.5 \%)\end{array}$ & $\begin{array}{l}3 \\
(37.5 \%)\end{array}$ & - & $25(39 \%)$ & $\begin{array}{l}13 \\
(20 \%)\end{array}$ & \\
\hline & $\begin{array}{l}\text { Some data } \\
\text { on } \\
\text { computer }\end{array}$ & $\begin{array}{l}11 \\
(52.4 \%)\end{array}$ & - & - & $\begin{array}{l}13 \\
(37.1 \%)\end{array}$ & - & - & $\begin{array}{l}2 \\
(25.0 \%)\end{array}$ & - & - & $26(41 \%)$ & - & - \\
\hline \multirow[t]{2}{*}{$\begin{array}{l}\text { Frequency } \\
\text { of updating } \\
\text { data }\end{array}$} & $\begin{array}{l}\text { Conti- } \\
\text { nuous } \\
\text { process }\end{array}$ & $\begin{array}{l}12 \\
(57.1 \%)\end{array}$ & & & $\begin{array}{l}27 \\
(77.1 \%)\end{array}$ & & & $\begin{array}{l}5 \\
(62.5 \%)\end{array}$ & - & - & $\begin{array}{l}44 \\
(68.8 \%)\end{array}$ & - & - \\
\hline & More than & $1(4.8 \%)$ & - & - & $3(8.6 \%)$ & - & - & 0 & - & - & $4(6.3 \%)$ & - & - \\
\hline
\end{tabular}




\section{BADLEy, D. HiLl \& N. WRAY}

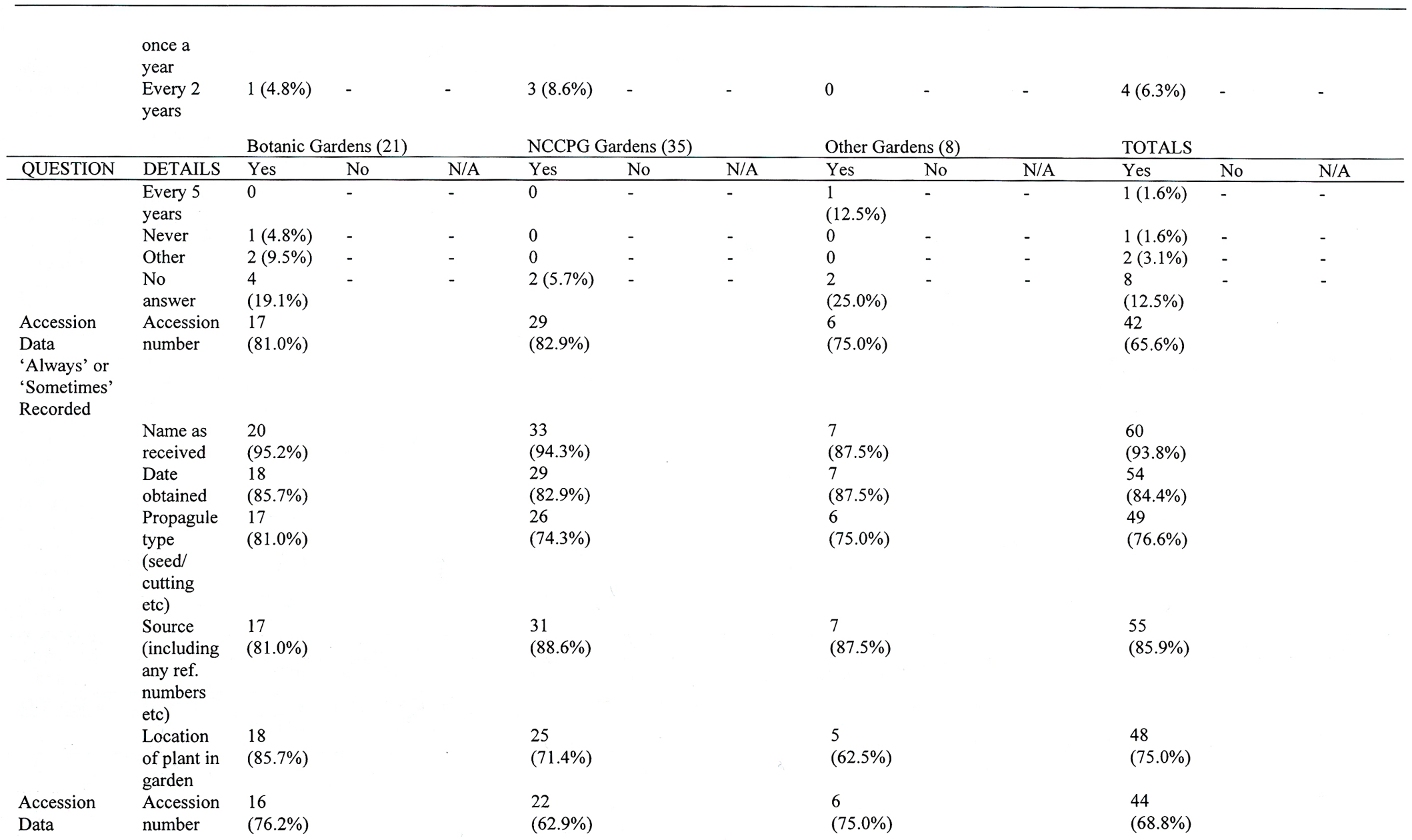


INADEQUATE ACCESSION DATA ...

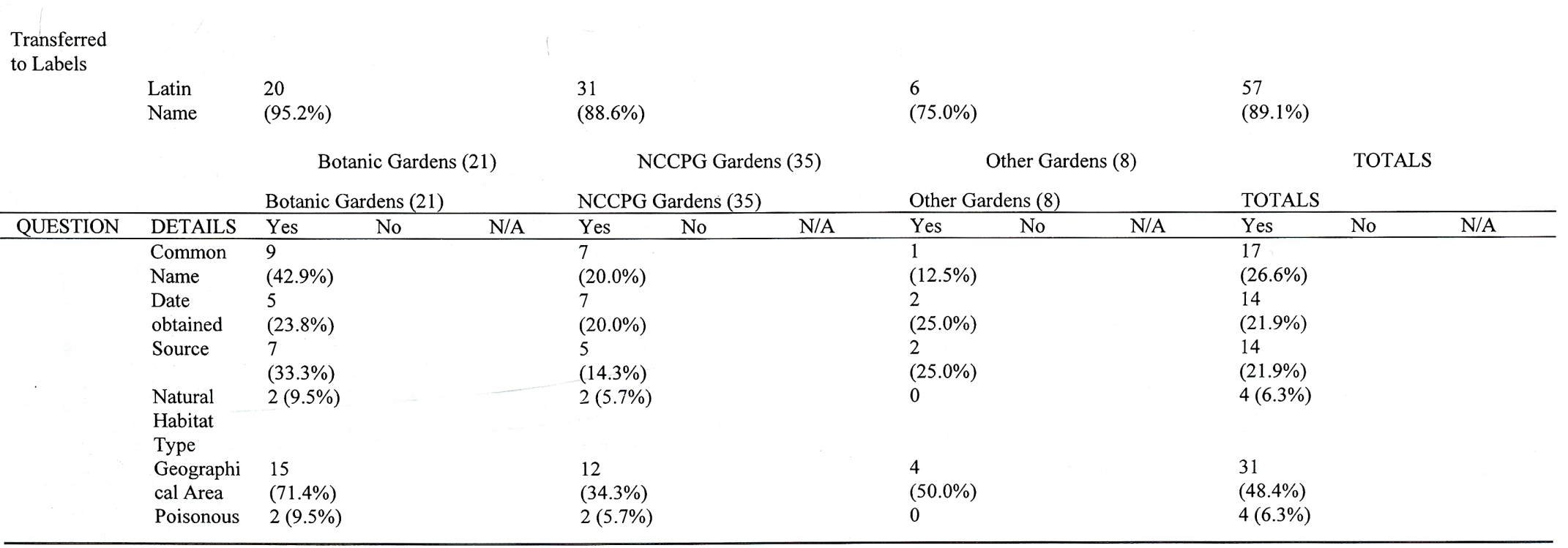




\section{Proposed CHECKLIST For CHOOSING PLANT SPECIES FOR A CONSERVATION}

COLLECTION

\section{Resources and Suitability of the Growing Site}

Staff available with the required skills to carry out:

Costing plan drawn up for the initial labour and material costs and the on-going expense of maintenance. Funding available for:

\section{Verification of plants.}

Documentation of collection on suitable computer database.

Regular maintenance.

Seed collection.

Propagation.

The purchase/collection of plants

Planting and landscaping

Documentation.

Labelling.

Maintenance of the plants.

Space with a similar habitat, soil, climate and environment to the species' native habitat.

No local pests and diseases which could destroy the collection or infect a native population if plants from the collection are to be used in reinstatement programmes.

Space for a field gene collection.

\section{The Genus/Species}

The genus includes species which are Endangered OR Rare OR Threatened in its native habitat as defined by the Red Data Book.

If it is included in the IUCN Red List

$$
\text { Category applies: }
$$

Locally

Regionally

Nationally

Internationally

The genus/species is rare in cultivation.

The genus/species is local.

The genus/species has an already known direct benefit to mankind (food, medicine).

It is used by the native population for medicine or other uses.

Someone would benefit from the conservation of this genus/species (e.g. ecotourism).

The genus/species has: Ecological significance

Taxonomic significance

Evolutionary significance

Any unusual features not already covered by the list above

Educational value which is easy to demonstrate - e.g. physiology, anatomy

Species has a genetic significance e.g. resistance to disease.

There are other conservation collections that this collection could complement. 
The pollination type, reproduction, seed viability and the viability of the population in the natural habitat is known.

A population viability analysis has been carried out.

Pollination will not need to be assisted.

Gene erosion in the collection can be prevented.

Hybridisation with other taxa of the same species in the garden needs to be considered and can be dealt with.

Propagation techniques known.

Its origin - specimens can be obtained from conservation workers in the field.

There would be no problems with collecting/obtaining samples because of local laws or the CITES regulations.

If from the Southern Hemisphere the plants would adjust to the Northern Hemisphere.

(Would seed be easier to use?)

The genus/species is hardy.

The plants will survive winter without protection.

Irrigation will not normally be needed.

The locality of the proposed collection is free from: Excessive pollution.

Extreme climatic conditions.

Damage by visitors.

The altitude of the site is comparable with that of the natural habitat of the genus/species.

The mature collection will fit physically in the space available.

The plants will not have invasive roots or seeds.

Rare specimens can be protected against theft.

\section{The Research and Educational Potential and Display}

On-going (preferably local) research/reinstatement programme related to this genus/species (In the UK the Biological Action Plan will indicate this).

The collection could be used to illustrate current and/or local research programmes.

The genus/species inspires a theme for the collection (e.g. geographical, habitat type).

Ecotourism aspects - the collection could illustrate the flora of a specific country.

The display could attract sponsorship to the garden.

The horticultural significance of the collection can be displayed.

Display boards, leaflets or other informative material to exploit its educational value can be provided.

The collection could form an interesting visual display - flower/leaf colour/bush shape. 
